\title{
PERUBAHAN BUDAYA TINGGI BERITA INVESTIGASI MENJADI BUDAYA POPULER
}

\author{
Roswita Oktavianti \\ Fakultas Ilmu Komunikasi, Universitas Tarumanagara \\ roswitao@fikom.untar.ac.id
}

\begin{abstract}
ABSTRAK
Karakteristik media massa sebagai sumber informasi terus berubah mengikuti dinamika regulasi dan perkembangan industri media. Perubahan ini berdampak tidak hanya pada program hiburan tetapi juga program siaran berita. Sebagai konten dengan budaya tinggi (high culture), program berita investigasi seharusnya diproduksi melalui sejumlah tahapan investigatif dengan konten dan kualitas yang berbeda dengan berita reguler. Pada kenyataannya, pekerja media dituntut bekerja secara instan mengikuti logika industri media. Berita investigasi berubah dari semula memiliki budaya tinggi menjadi budaya populer (popular culture). Dengan pendekatan kualitatif dan metode studi kasus maka penelitian ini bertujuan mengetahui bagaimana pekerja media menciptakan berita investigasi dari budaya tinggi menjadi budaya populer. Teknik pengumpulan data primer berupa wawancara dilakukan kepada informan, pekerja media di salah satu program investigatif televisi swasta. Penelitian menemukan bahwa industri budaya pada berita investigasi dilakukan pada tidak hanya pada konten tetapi juga sumber daya manusia di dalamnya. Berita investigasi diproduksi oleh jurnalis yang sebagian besar tanpa kompetensi investigasi. Berita investigasi berpatokan pada besarnya kuantitas berita yang dihasilkan, durasi produksi yang singkat, efisiensi anggaran, selera pasar, serta kepentingan pemilik dan pengiklan. Perubahan program berita investigasi dari budaya tinggi ke budaya populer ini pada akhirnya berdampak pada kualitas berita investigasi.
\end{abstract}

Kata kunci: berita investigasi, industri budaya, budaya tinggi, budaya populer

\section{PENDAHULUAN}

Industri televisi mengalami peralihan dari era budaya kerja agraris ke era budaya kerja industri. Menurut Garin Nugroho, seorang sutradara dan pengamat pertelevisian, efisiensi dan efektivitas kerja dalam industri televisi Indonesia masih berorientasi pada sasaran ekonomi jangka pendek. Hal ini jelas terlihat pada program berita investigatif. Program berita investigatif yang ditayangkan di seluruh stasiun televisi mengklaim sebagai berita investigasi, namun dengan proses peliputan yang sangat jauh dari prinsip-prinsip jurnalisme investigasi (Panjaitan \& Iqbal, 2006).

Berita investigatif merupakan berita mendalam yang mencoba menyingkap hal-hal yang ditutupi dan menyelidiki fakta-fakta yang tersembunyi (Wibowo, 2007). Liputan dengan kategori investigatif di Indonesia pernah dilakukan oleh wartawan senior (Alm) Bondan Winarno dengan laporan setebal 270 halaman. Dalam liputannya mengungkap fakta skandal Busang, Bondan mengunjungi langsung kompleks pemakaman mewah di Manila, Filipina. Lokasi makam Michael Antonio Tuason de Guzman, eksekutif perusahaan tambang asal Kanada, Bre-X yang tewas bunuh diri melompat dari helikopter di pedalaman Kalimantan pada 19 Maret 1997 itu kemudian diketahui tidak pernah dikunjungi. Tidak ada karangan bunga, bekas dupa atau lilin sehingga menguatkan dugaan bahwa jenazah yang dikubur bukanlah Guzman.

Sebagai jurnalis investigasi, Bondan berusaha mengungkap misteri dibalik kematian Guzman, setelah Guzman diketahui melontarkan temuan palsu terkait adanya kandungan emas di 
Busang, Kalimantan Timur. Bondan tidak hanya meneliti sejarah hidup Guzman di Indonesia dan Filipina, ia juga membidik pemerintah 'kroni Cendana' yang kala itu siap menjadi mitra lokal bagi investasi asing; mewawancari dokter, polisi, dan keluarga; menelusuri hutan rimba Busang di pedalaman Kalimantan Timur, dan perusahaan Bre-X di Calgary dan Toronto, Kanada yang ditengarai meraup keuntungan besar dari melonjaknya harga saham atas temuan itu (Laksono, 2010).

Hal yang sama juga dilakukan oleh sejumlah wartawan progresif yang tergabung dalam organisasi Philippine Center for Investigating Journalism (PCIJ) dalam mengungkap bisnis berbau KKN, real estate, koleksi rumah mewah mantan Presiden Filipina Joseph Estrada. PCIJ mempraktikkan "muckraking journalism”, sebuah genre jurnalisme untuk mengungkap kasuskasus korupsi. Investigasi PCIJ menghabiskan waktu berbulan-bulan. Namun data yang diperoleh signifikan bahkan tim menemukan persoalan lain di lapangan seperti protes penduduk atas pembangunan perumahan. Protes itu diinvestigasi lagi hingga ditemukan adanya kejanggalan dalam penerbitan izin dan lisensi (Sudibyo, 2001).

Di televisi, laporan investigasi dikemas dalam program khusus berdurasi 30 menit seperti Metro Realitas (Metro TV), Delik (RCTI), atau Sigi (SCTV). Adapula yang menempel pada program berita regular. Namun, program yang ditayangkan itu belum tentu investigatif. Kadangkala, wartawan hanya menggunakan teknik investigasi. Berita itu kemudian dilabeli sebagai laporan investigasi meski tidak memenuhi kaidah berita investigasi.

Dalam merencanakan sebuah produksi program televisi, produser dihadapkan pada lima hal yaitu materi produksi, sarana produksi, biaya produksi, organisasi pelaksana produksi, dan tahapan pelaksanaan produksi. Hal ini juga berlaku bagi program berita. Siaran berita harus memiliki profesionalisme yang tinggi, akurasi, aktualisasi dan biaya tinggi. Untuk menutupi biaya tinggi maka harus diimbangi dengan pemasukan yang tinggi. Dengan demikian, kepentingan bisnis tidak hanya pada program hiburan tetapi juga dalam urusan siaran berita (Wibowo, 2007).

Dalam membuat berita investigasi, terdapat tiga hal yang perlu dilakukan reporter investigatif. Pertama, surface fact yaitu penelusuran fakta dari sumber orisinal seperti rilis berita, catatan tangan, dan pembicaraan, mengobservasi berbagai kejadian dan mencari sumber informasi. Kedua, reportorial enterprise meliputi verifikasi, menyelidiki, meliput kejadian mendadak, mengamati latar belakang. Ketiga, interpretation and analysis yakni mencoba mengukur akumulasi informasi berdasar signifikansi, dampak, penyebab, dan konsekuensinya (Santana, 2006).

Berita dengan label "investigasi" mampu menarik perhatian khalayak. Namun, dengan tekanan ekonomi media, wartawan atau jurnalis televisi mencari cara untuk menyajikan berita tersebut dalam waktu yang terbatas. Tidak sesuai dengan kebutuhan dalam membuat produk investigatif. Jurnalis bekerja berdasarkan logika industri di mana sesuatu diproduksi untuk khalayak luas dan berorientasi pada pasar. Kalaupun ditujukan untuk kalangan terbatas, produk tersebut memiliki kapasitas ekonomi atau daya topang ekonomi.

Media memberi kesenangan, membawa orang-orang berhubungan dengan dunia luas, menyajikan kesenangan, kenikmatan, dan hiburan, menghilangkan kebosanan dan kesendirian dengan berbagai konten 'populer'. Ini yang disebut dengan budaya populer (Witkin, 2003). Dalam hal ini budaya tinggi atau high culture, menciptakan budaya yang populer atau popular culture. 
Budaya tinggi berbeda dari seluruh selera budaya karena didominasi oleh pencipta dan kritikus, dan seluruh penggunanya menerima standar dan perspektif penciptanya. Ini adalah budaya 'keseriusan' dari penulis, artis, dan sejenisnya, dan oleh karena itu memasukkan proporsi penting dari penciptanya (Gans, 1974). Sementara budaya populer merupakan ruang 'konstruksi' yang menghasilkan budaya, konstruksi yang diuji ke pasar dari efek yang dapat diprediksi dan dikalkulasi (Witkin, 2003).

Penelitian ini ingin mengetahui bagaimana pekerja media menciptakan berita investigasi dari budaya tinggi (high culture) menjadi budaya populer (popular culture)? Dengan demikian dapat digali persoalan menyangkut peran pekerja media khususnya media televisi, dan kualitas berita investigasi di Indonesia.

\section{METODE PENELITIAN}

Penelitian ini menggunakan pendekatan kualitatif untuk mendapatkan pemahaman tentang pemikiran, kepercayaan, dan motivasi, melalui pertanyaan mengapa, bagaimana, apa proses yang terjadi, apa saja pengaruh atau konteks yang ada. Metode penelitian yang digunakan yakni studi kasus. Menurut Yin, studi kasus merupakan metode penelitian. Sama seperti strategi penelitian lainnya, merupakan cara menginvestigasi suatu fenomena kontemporer dalam konteks di kehidupan nyata terutama ketika batasan antara fenomena dan konteks tidak terlihat jelas (Yin, 2003). Studi kasus dilakukan terhadap jurnalis program berita investigasi di stasiun televisi dalam kelompok Media Nusantara Citra (MNC).

Metode pengumpulan data berupa wawancara terhadap partisipan (interviewee) yang dipilih secara sengaja (Hennink, Hutter, \& A, 2011). Wawancara dilakukan terhadap dua partisipan yakni pelaku industri media massa program berita investigasi di salah satu stasiun televisi dalam kelompok MNC. Dalam pembahasan, peneliti menggunakan sebutan informan untuk kedua partisipan. Peneliti menggunakan pertanyaan terbuka dan menggali hasil respon yang mendalam tentang pengalaman, persepsi, opini, perasaan, dan pengetahuan partisipan (Paton, 2002). Di samping itu, penelitian ini juga merupakan studi dokumentasi dengan pengumpulan data sekunder berupa literatur terkait liputan investigatif. Dengan demikian, studi ini merupakan perpaduan antara kerja lapangan dan kerja pustaka.

Setelah melakukan wawancara dan data terkumpul, peneliti melakukan analisis data kualitatif. Kemudian data tersebut diklasifikasikan ke dalam kategori-kategori dengan mempertimbangkan kesahihan dan kompetensi subyek penelitian, tingkat autentisitasnya, dan triangulasi berbagai sumber data (Kriyantono, 2006). Triangulasi dalam hal ini dilakukan dengan sumber data sekunder.

\section{HASIL DAN PEMBAHASAN}

\subsection{Kepentingan Pengusaha atau Pemilik}

Intervensi pemilik seringkali terjadi saat menggarap sebuah program berita. Partisipan menyatakan bahwa agenda setting yang dibangun oleh redaksi mempengaruhi 90 persen peliputan. Partisipan mencontohkan berita kasus KTP elektronik yang menyeret sejumlah pejabat negara dan pengusaha harus mengikuti sejumlah arahan dari redaksi. Ada pembatasan terhadap narasi dan gambar terhadap pihak-pihak yang memiliki kedekatan dengan pemilik. 
Hal yang sama terjadi dalam berita penutupan hotel yang ditengarai sebagai lokasi prostitusi “Alexis" oleh Gubernur DKI Jakarta Anies Baswedan. Liputan investigasi ini awalnya bermaksud mengkritisi tindakan Anies menutup Alexis, tanpa memberlakukan hal yang sama pada lokasi prostitusi lain di Jakarta. Kebijakan ini dinilai hanya untuk memenuhi janji kampanye. Namun, menjelang siaran, judul berita diubah dengan menunjukkan keberpihakan kepada Anies.

Seorang produser profesional berupaya mencari cara bagaimana materi produksi selain menghibur, juga dapat menjadi sajian yang bernilai, dan memiliki makna. Produser harus memiliki visi agar menciptakan produksi yang bernilai atau berbobot. Namun, setiap sistem pemberitaan memiliki karakteristik khusus. Suatu sistem, memiliki tekanan pada peranan dan kepentingan sosial salah satunya kepentingan politik (Wibowo, 2007). Grup MNC dimiliki oleh Ketua Umum Partai Persatuan Indonesia (Perindo), Hary Tanoesoedibjo. Saat kampanye pemilihan kepala daerah DKI Jakarta, Hary mendeklarasikan dukungannya kepada pasangan calon gubernur dan wakil gubernur, Anies Baswedan dan Sandiaga Uno (Antony, 2017).

Selain pemilik media, pengiklan juga mempengaruhi pemberitaan. Seperti disampaikan oleh partisipan.

Kami pernah mau liputan ditolak oleh manajemen karena berkaitan dengan iklan. Kami agak kecewa. Kami pernah mau liputan soal kooptasi $\mathrm{A}^{* * *}$ tetapi karena $\mathrm{A}^{* * *}$ jadi pengiklan di sini harus berpikir ulang. Bos kami bilang, 'dipikir ulang'. Cuma kami menerjemahkan itu, 'dilarang'.

Cara pandang utama/pendekatan untuk menganalisis hubungan antara kepemilikan dan kontrol dilihat dari konstruksi terhadap isu tertentu. Cara pandang instrumental terlihat dari pilihan berita yang disajikan. Tatanan instrumental berarti bahwa keinginan dan kebutuhan subyektif bisa dipenuhi hanya jika diasimilasikan dengan rasionalitas (Witkin, 2003). Dalam hal ini, pemilik dan manajer sepakat menentukan apa yang boleh muncul (orang, fakta, gagasan) ke hadapan publik. Atas dasar itulah, pemilik memilih direksi/orang yang sejalan dengan kepentingannya. Apa yang terjadi pada program investigatif di atas merupakan hubungan antara kepemilikan dan kontrol yang bersifat straight forward. Pemikiran ini biasanya terlihat dalam rapat redaksi.

Peran utama media massa dalam industri kebudayaan, membuat khalayak menerima ideologi kapitalisme sebagai kebenaran. Media massa telah terkunci dengan struktur kekuasaan dan tidak akan bertindak di luar itu. Setelah tumbuh menjadi industri cara pandang datang dari elit dominan. Menurut analisis Marx tentang kapitalisme, obyek yang 'dimanufaktur/diproduksi' merupakan komoditas. Obyek tersebut bukan hasil dari proses sosial 'organik', bukan ekspresi atau realisasi dari proses hidup 'komunitas' asli (Witkin, 2003).

\subsection{Cara Kerja Peliputan Investigatif}

Program investigatif di salah satu stasiun televisi pada grup MNC ini tayang satu kali dalam sepekan pada akhir pekan. Program berita ini tayang dini hari di atas pukul 24.00. Tim investigatif terdiri dari tiga reporter, tiga juru kamera, satu editor, dan satu produser. Jumlah ini dinilai tidak ideal. Dengan jumlah tim tersebut maka narasumber membuat sistem penugasan yakni satu reporter bertanggung jawab dengan satu tema deadline per minggu. Dengan demikian, satu 
reporter memiliki waktu liputan di lapangan selama lebih dari dua minggu, sisanya digunakan untuk membuat naskah, proses penyuntingan (editing), dsb. Berita penutupan hotel "Alexis" dilakukan selama dua minggu.

Kondisi ini tidak sesuai dengan karakteristik reportase lanjutan yang membutuhkan waktu lebih panjang. Reportase ini ditujukan untuk membuat in-depth journalism atau investigative journalism (Junaedi, 2013). Corak berita ini bertolak dari suatu fakta yang diduga memiliki latar belakang tidak beres. Dalam mengungkapkan ketidakberesan terrsebut perlu diturunkan tim jurnalis untuk menyelidiki fakta yang terlihat di permukaan dan fakta tersembunyi. Temuan lalu dibandingkan, dianalisis, dan ditayangkan dalam siaran berita (Wibowo, 2007). Namun menurut William, banyak reporter merasa mendapat fakta dan kisah investigatif. Padahal, reporter seringkali hanya mengungkap kisah keseharian dari seorang narasumber atau hanya menyampaikan protes atas ketidakpedulian masyarakat terhadap suatu masalah (Santana, 2006).

Partisipan mengakui, program berita investigatif yang diproduksi kerap dikategorikan sebagai berita investigasi termasuk dari pihak manajemen stasiun televisi. Namun kenyataanya, program berita tersebut belum termasuk program investigasi murni. Program berita tersebut masuk dalam kategori program in-depth reporting dengan teknik-teknik liputan menggunakan teknik liputan investigasi. Sepertihalnya teknik investigasi berita televisi, program investigatif ini juga menggunakan kamera tersembunyi (candid camera), hingga penyamaran narasumber (undercover). Tim investigatif membayar narasumber berita tergantung pada informasi yang bisa diperoleh dari narasumber tersebut.

Logika pasar juga berlaku bagi liputan investigatif televisi. Hal ini ditunjukkan dari pemilihan topik berita. Berita penting seperti kasus Bantuan Likuiditas Bank Indonesia (BLBI) tidak menjadi prioritas isu yang diangkat. Pasalnya, tim investigatif harus melakukan visualisasi terhadap kasus yang terjadi tahun 1990-an itu.

Menurut senior-senior isu BLBI itu bagus tapi bagaimana memvisualkan isu itu. Itu yang tidak kami temui di televisi. Dengan durasi liputan hanya dua minggu, kami harus memvisualkan berita itu agar nyaman dilihat pemirsa walaupun isinya berat, belum lagi memilih narasumbernya, terkejar tidak dengan dua minggu?

Hal yang sama juga dilakukan dalam memilih sudut pandang atau angle berita. Misalnya dalam kasus gugatan perdata anak kandung terhadap orangtua. Jika dilihat dari sisi hukum, gugatan tersebut bisa terjadi karena orangtua diduga melakukan perbuatan melawan hukum. Gugatan anak terhadap orangtua seperti ini sudah biasa terjadi di negara lain. Partisipan awalnya mengusulkan sudut pandang berita, menyikapi regulasi di Indonesia, atau kepentingan siapa yang bermain di belakangnya. Namun, angle pemberitaan tersebut dinilai tidak sesuai dengan keinginan khalayak. Tim investigatif harus menempatkan benak khalayak di dalam pikiran. Dengan jam tayang dini hari, maka program acara harus menarik. Apalagi, khalayak Indonesia sebagian besar belum sadar hukum. Maka angle berita yang dipilih pun sama dengan media massa lain yakni sisi humanis orangtua atau sikap arogan anak terhadap orangtua. Dengan topik tersebut, program berita lebih menarik dan mampu bermain pada tataran emosional penonton.

Dalam hal ini, pekerja media bukan diperintah untuk kepentingan pengusaha atau pemilik tetapi ada logika industri sehingga yang dihasilkan adalah berita-berita sensasional. Ditambahlagi 
di era reformasi dengan kebebasan pers, muncul praktik mengemas informasi mengenai 'konflik', 'sensasi', 'gosip, 'seks', 'kekerasan', 'kisah mistik atau misteri' sebagai komoditi yang banyak dijual. Praktik ini disebut jurnalisme selera rendah yang saat ini merambah ke media elektronik (Sendjaja, 2008).

Dengan jam tayang dini hari maka tim investigatif harus merebut atensi penonton. Para perancang program harus menempatkan pertimbangan demografi dan sosiografi penonton di benak mereka. Cara pandang ini merupakan cara pandang struktural. Secara struktural, media massa bukan hanya instrumen pemilik modal, melainkan harus beroperasi dengan logika industri. Ada ragam kepentingan yang harus dihadapi pekerja media diantaranya kepentingan pemilik modal, manajemen, pengiklan, rekan kerja/profesional, distributor, teknologi dan konsumen.

\subsection{Anggaran Investigatif}

Liputan investigatif awalnya digarap serius dengan anggaran besar. Pada awal program investigatif ini diperkenalkan kepada masyarakat, untuk membuat tayangan yang menggambarkan pembunuhan di diskotek, tim mengeluarkan dana hingga Rp50 juta untuk membuat setting lokasi di studio. Namun, dengan semakin banyak televisi komersial yang menyuguhkan program menarik, maka kompetisi antar berita investigasi semakin ketat. Sementara, anggaran program investigasi mengalami penurunan.

Minimnya anggaran menyebabkan liputan investigatif tidak komprehensif membongkar fakta. Misalnya, dalam liputan investigatif tentang ijazah palsu, tim tidak bisa memperoleh gambar lokasi pembuatan ijazah palsu karena dana yang diminta oleh narasumber cukup tinggi. Bahkan, masalah pendanaan juga menyebabkan sebuah berita investigasi yang sudah direncanakan, tidak dilanjutkan kembali.

Pasca integrasi menjadi satu grup media di bawah payung MNC, jumlah dana peliputan investigasi yang cukup besar harus disiasati. Partisipan mencontohkan, anggaran liputan ke salah satu pulau yang diduga terjadi pencemaran pernah mencapai Rp30 juta. Setelah integrasi dengan MNC Grup, anggaran sebesar itu diperbolehkan oleh manajemen asalkan tim bisa memproduksi dua program sekaligus. Pengetatan anggaran juga dilakukan dengan menyiasati biaya peliputan dalam dan luar kota, pemilihan tema yang berpatokan pada rating dan share yang tinggi.

Dua tahun setelah integrasi, membuat budget-nya, dalam satu bulan itu ada tema dengan budget besar misalnya ke luar kota dengan Rp20-30 juta dalam satu tema. Tapi tiga episode berikutnya cari isu-isu di Jakarta dengan hanya menghabiskan 2-3 juta.

Keberhasilan penjualan barang dan jasa melalui iklan ditentukan oleh banyaknya audiensi yang dimiliki suatu program. Rating menjadi indikator apakah program tersebut memiliki audiensi dan menjadi perhatian pemasang iklan (Djamal \& Fachruddin, 2011). Rating yang baik berdampak pada tarif iklan yang lebih tinggi. Itu berarti lebih banyak pendapatan untuk perusahaan (Tassel \& Poe-Howfield, 2010). Sementara itu, share berperan dalam mengetahui kualitas program dibandingkan dengan kompetitor (Djamal \& Fachruddin, 2011). Share dihitung dengan membagi jumlah rumah tangga yang menonton program dengan jumlah rumah tangga yang menggunakan televisi pada waktu tertentu (Straubhaar, LaRose, \& Davenport, 2012) 
Selain dari sisi pendanaan, partisipan mengatakan bahwa integrasi juga menyebabkan perubahan sumber daya manusia (SDM). Pasca integrasi, reporter disatukan dalam satu bagian atau gathering. Ini menyebabkan jumlah reporter dan juru kamera tim investigatif tidak sesuai dengan kebutuhan. Terlebih lagi, reporter dan juru kamera investigatif dituntut memiliki kemampuan reportase lebih baik dari reporter dan juru kamera program berita reguler.

Kami ingin konsepnya investigasi yang pure cuma kadang terkendala deadline, sementara SDM kami cuma dua yang tiap minggu harus di-push terus.

\subsection{Budaya Tinggi ke Budaya Populer}

Dallas Smythe menyebut pada dasarnya, khalayak adalah komoditas sementara media massa, dan pengiklan adalah pembeli. Pelaku media memperhitungkan skala ekonomi dan lingkup ekonomi suatu acara/program. Skala ekonomis adalah kondisi di mana produksi yang meningkat, menghasilkan biaya rata-rata per unit yang semakin rendah. Sedangkan pemanfaatan lingkup ekonomi, yakni ketika suatu perusahaan dapat menghasilkan lebih dari satu atau beberapa jenis produksi barang dan jasa dengan menggunakan fasilitas produksi yang sama (Noor, 2010).

Dengan logika sebagai industri padat modal, maka lembaga penyiaran tidak lagi dimanfaatkan sebesar-besarnya bagi kepentingan publik. Kesuksesan sebuah program ditentukan oleh seberapa banyak pengiklan yang bersedia memasang iklan di program tersebut. Ini menyebabkan, media komersial cenderung menyajikan program berselera rendah sesuai dengan apa yang paling banyak diminati khalayak.

Liputan investigatif yang seharusnya dilakukan secara komprehensif dan dalam rentang waktu cukup panjang, follow the truth, serta memperhitungkan akibat yang ditimbulkan, menjadi tergradasi. Liputan investigatif kemudian dilakukan secara 'stripping' atau kejar tayang dengan asumsi, produksi, dalam jumlah besar akan lebih menguntungkan daripada produksi dalam jumlah sedikit. Produktivitas, akan menentukan keuntungan yang diperoleh. Suatu berita investigatif di televisi bisa disajikan satu kali dalam seminggu. Waktu yang dibutuhkan tim investigatif untuk mencari fakta dan melaporkan pada khalayak cukup singkat. Sementara untuk menghasilkan sebuah liputan investigatif yang berkualitas dan kredibel seorang jurnalis membutuhkan waktu berbulan-bulan hingga bertahun-tahun.

Produksi berita investigatif dikerjakan oleh tim yang terbatas. Ketiadaan training/pelatihan khusus bagi para jurnalis investigatif membatasi kapasitas jurnalis untuk melakukan laporan mendalam (Coronel, 2000). Ini berdampak pada kualitas berita investigatif yang ditayangkan. Pelaku media berorientasi pada pemenuhan permintaan (penonton dan pengiklan), namun mengabaikan kualitas. Industriawan memandang berita investigatif sebagai dagangan yang bersifat jangka pendek. Sementara, pelaku industri budaya (jurnalis) yang awalnya dinilai memiliki kesejahteraan lebih baik akhirnya dimanfaatkan dalam konvergensi media.

Konvergensi merupakan efek lanjut dari industrialisasi media yang membuat pekerja media lebih kreatif karena tekanan efisiensi sumber daya manusia, target produk, dan anggaran karena ketatnya persaingan antar program media. Bahkan persaiangan program media dalam satu kelompok perusahaan (Oktavianti, 2018). 
Pemindahan dari budaya tinggi menyebabkan budaya mengalami penurunan kualitas. Dalam konteks penelitian ini, sebuah kerja investigatif yang pada dasarnya dikumpulkan berbulanbulan bahkan bertahun-tahun, menjadi hanya dikumpulkan dalam waktu seminggu bahkan dalam hitungan hari. Hasilnya ditayangkan dalam program berdurasi setengah jam. Hal ini terus berlangsung secara kontinu mengikuti permintaan pasar, yakni konsumen/penonton dan pengiklan.

Liputan investigatif semacam ini melahirkan dampak buruk bagi masyarakat. Namun, sebagian besar masyarakat tetap mengonsumsi produk industri budaya tersebut tanpa kritik dan gugatan. Pola pikir masyarakat mengikuti industri kebudayaan yang merupakan bagian dari kapitalisme. Peran utama media massa dalam industri kebudayaan, membuat khalayak menerima ideologi kapitalisme sebagai kebenaran atau menciptakan hegemoni ideologi. Ideologi kemudian ditanamkan secara kasat mata oleh aparatus ideologis melalui program-program yang disajikan. Produk media diciptakan karena adanya kepentingan ekonomi. Di era informasi, media sudah dianggap kebenaran itu sendiri. Masyarakat langsung percaya pada apa yang disampaikan media dengan menjadikan informasinya sebagai bahan pembicaraan publik (Santana, 2006).

Dengan logika industri yang mencari keuntungan maka yang dipertaruhkan adalah faktor ekonomi yang lebih besar. Dengan menjadi industri pabrikan maka produk yang dihasilkan mengikuti standarisasi dan bersifat homogen serta bisa dijual. Budaya tinggi harus hidup dengan standar masing-masing pengguna dan penciptanya. Budaya akan melayani pengguna dan penciptanya (Gans, 1974)

\section{KESIMPULAN DAN SARAN}

Industri budaya terjadi pada program berita investigasi di televisi. Dampak dari industri budaya yakni terjadi pergeseran berita investigasi dari budaya tinggi menjadi budaya populer. Pergeseran ini terjadi pada pekerja media dan produk investigasi yang dihasilkan. Berita investigasi yang seharusnya dilakukan secara komprehensif dalam rentang waktu cukup panjang telah bergeser. Berita investigasi lebih mengutamakan kuantitas yakni produksi dalam jumlah besar, dalam waktu singkat, serta anggaran terbatas. Berita investigasi tidak lagi memiliki standar yang mutlak sebagai liputan investigatif. Selain itu, berita investigasi yang pada dasarnya mencari kebenaran serta memperhitungkan akibat yang ditimbulkan, juga mengikuti selera pasar dan kepentingan pemilik serta pengiklan. Berita investigasi berubah menjadi budaya popular. Akibatnya kualitas berita mengalami penurunan. Sebagai produk budaya tinggi, jurnalis berita investigasi seharusnya memiliki kompetensi lebih baik dan pengalaman peliputan lebih lama daripada jurnalis regular. Dengan tuntutan kuantitas, maka sumber daya manusia yang diturunkan pun mengikuti mengalami penurunan kualitas.

Penelitian ini diharapkan mampu menjadi referensi bagi penelitian terkait industri budaya pada program-program televisi. Kaum intelektual bisa menjadi agensi untuk mengubah pola pemikiran ini dengan melahirkan penelitian-penelitian yang kritis terhadap suatu fenomena. Selain itu, penelitian ini juga bisa menjadi masukan bagi praktisi media (jurnalis), pemilik media, pengiklan dan pemerintah. Jurnalis merupakan kaum intelektual yang dianggap mampu melakukan perubahan di ruang redaksi. Pemilik media menjadi agensi yang membawa pada perubahan dengan tidak melakukan intervensi terhadap kerja jurnalistik. Perubahan juga bisa terjadi jika pemasang iklan lebih memprioritaskan mendukung program/acara yang berkualitas 
ketimbang mematok pada rating. Pasalnya, stasiun televisi komersial mengandalkan pada iklan. Sedangkan dari sisi pemerintah perlu melakukan intervensi dengan menjamin hak publik mendapatkan pelayanan terbaik. Frekuensi milik publik dan konten di dalamnya harus ditata. Setiap tayangan diawasi dan ditindak tegas. Hal ini karena regulasi televisi sebagai media besar yang berpengaruh pada pemikiran masyarakat Indonesia terlalu lemah.

\section{Ucapan Terima Kasih (Acknowledgement)}

Peneliti mengucapkan terimakasih kepada Direktorat Penelitian dan Pengabdian Kepada Masyarakat Universitas Tarumanagara atas dukungan berupa pendanaan dalam penelitian ini.

\section{REFERENSI}

Antony, Noval Dhwinuari. (2017, Maret 14). https://news.detik.com. Retrieved Maret 11, 2018, from https://news.detik.com/berita/d-3446694/dukung-anies-hary-tanoe-jakarta-harusmengayomi-semua-pihak.

Babbie, Earl. (2011). The Basics of Social Research, Fifth Edition. CA, USA: Wadsworth Cengage Learning.

Coronel, Sheila S. (2000). Bertrayals of The Public Trust, Investigative Reports on Corruption. Manila: PCIJ.

Creswell, John. W. (2009). Research Design Third Edition. California, USA: Sage Publication.

Denzin, Norman K., \& Lincoln, Y. S. (2009). Handbook of Qualitative Research. CA: Sage Publication.

Djamal, Hidajanto \& Fachruddin, A. (2011). Dasar-Dasar Penyiaran: Sejarah, Organisasi, Operasional, dan Regulasi. Jakarta: Kencana Prenada Media Group.

Gans, H. J. (1974). Popular Culture and High Culture and Analysis and Evaluation of Taste. New York: Basic Book Inc.

Harsono, Andreas. (2015).http://www.andreasharsono.net/1999_02_01_archive.html.

Hennink, M., Hutter, I., \& A, B. (2011). Qualitative Research Methods. California: Sage Publications.

Junaedi, Fajar. (2013). Jurnalisme Penyiaran dan Reportase Televisi. Jakarta: Kencana Media Group.

Kriyantono, Rachmat. (2006). Teknik Praktis Riset Komunikasi. Jakarta: Kencana.

Laksono, Dandhy Dwi. (2010). Jurnalisme Investigasi: Trik dan Pengalaman Para Wartawan Indonesia Membuat Liputan Investigasi di Media Cetak, Radio, dan Televisi. Bandung: Mizan.

Noor, Henry Faizal. (2010). Ekonomi Media. Jakarta: Raja Grafindo Persada. 
Oktavianti, Roswita. (2018). Competitive Advantage of Investigation Products in Media Industrialization. IFIM's Focus International Journal of Management, 14(1), 6-12.

Panjaitan, E. L., \& Iqbal, T. D. (2006). Matinya Rating Televisi, Ilusi Sebuah Netralitas. Jakarta: Yayasan Obor Indonesia.

Paton, Michael Quinn. (2002). Qualitative Research and Evaluation Methods Third Edition. California: Sage Publications.

Santana, Septiawan. (2006, Desember). Wacana Investigative Reporting. MediaTor, 7(2), 213226.

Sendjaja, Djuarsa Sasa. (2008). Akuntabilitas Sosial Media Massa. Dahlan Alwi, Manusia Komunikasi, Komunikasi Manusia (459-474). Jakarta: Penerbit Buku Kompas.

Straubhaar, Joseph, LaRose, Robert, \& Davenport, Lucinda. (2012). Media Now: Understanding Media, Culture and Technology Seventh Edition. MA, USA: Wadsworth Cengage Learning.

Sudibyo, Agus. (2001, September-November). Resensi Buku Investigative Journalism, Jurnalismenya Kaum Partikelir. Jurnal Masalah-Masalah Sosial dan Politik Fakultas llmu Sosial dan Ilmu Politik Universitas Atma Jaya Yogyakarta, 3(3).

Tassel, Joan Van, \& Poe-Howfield, Lisa. (2010). Managing Electronic Media: Making, Marketing \& Moving Digital Content. Massachuset, USA: Focal Press Elsevier Inc.

Wibowo, Fred. (2007). Teknik Produksi Program Televisi. Yogyakarta: Pinus Book.

Witkin, Robert W. (2003). Adorno on Popular Culture. London: Routledge.

Yin, Robert K. (2003). Case Study Research Design \& Methods Third Edition. Thousand Oaks, California: Sage Publications. 